\title{
Rural Space Development in Post-transition Countries: The Case of Serbia
}

\author{
Emilija Manić, Svetlana Popović, and Žaklina StoJANović, all Belgrade \\ [Beograd]*
}

with 12 figures in the text

\section{Content}

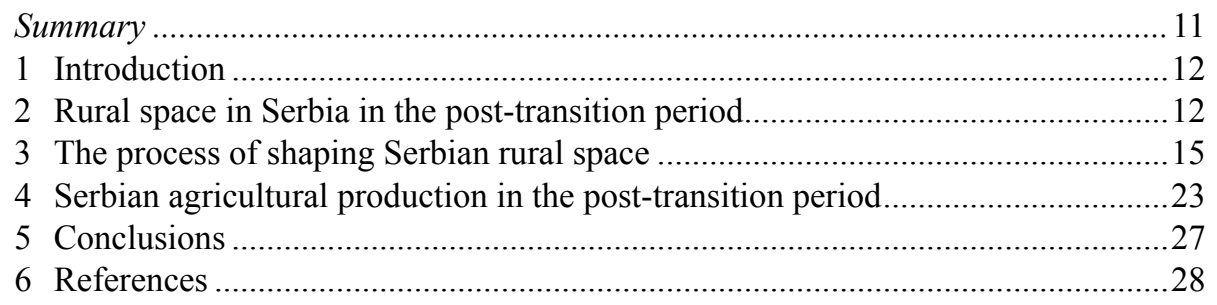

\section{Summary}

Different historical background of agricultural development as well as different economic and social circumstances during the transition period produced different rural space characteristics among Southeast European countries. This paper investigates the characteristics of rural space in Serbia during the period 2002-2013/14, as an example of rural space development in post-transition countries.

Serbian agriculture is characterised by different modes of agricultural production in the northern part of the country (Vojvodina) and Serbia proper. In Serbia proper, there are many small and fragmented family farms, mostly disorganised and with a very low rate of investment and lack of high-quality machinery. The situation in Vojvodina is slightly better, where the level of fragmentation is not as high and where modern agricultural production is developing. However, some economic indicators show the depth of structural economic problems in the whole country (rate of unemployment

* Emilija Manić, Prof. Associate PhD., Svetlana Popović, Prof. Assistant PhD., Žaklina StoJanović, Professor PhD., all University of Belgrade, Faculty of Economics, Kamenicka 6, Belgrade, Serbia; email: geografija@ekof.bg.ac.rs; ceca@ekof.bg.ac.rs; zaklina@ekof.bg.ac.rs 
and ratio between employed, unemployed and pensioners). Unfortunately, there are no big differences in demographic issues between Vojvodina and Serbia proper: Rural population has been constantly diminishing over the past five decades resulting in serious demographic problems, i.e. depopulation, unbalanced age structure, negative net migration rate.

\section{Introduction}

According to the Organisation for Economic Cooperation and Development's (OECD) classification, rural areas in Serbia make up $90 \%$ of its territory and are inhabited by approximately $66 \%$ of the Serbian population. These areas are characterised by significant differences in natural, demographic, infrastructural and other conditions for agricultural production, but also by common historical background and economic development. However, it is true for all parts of the country with the only exception of Vojvodina that Serbia's rural space is suffering from a constant process of depopulation, emigration and low economic performance. Some regional disparities in rural production are not so much due to structure, but to intensity of production.

In some aspects, it is possible to compare Serbian agriculture with the agriculture of other countries in Southeast Europe, which may be of special interest related to transition analysis. The change in the agricultural sector that occurred after 1989 is one of the most complex issues because it involved changes in ownership and privatisation of processing capacities as well as market liberalisation and the creation of a new economic and business environment. As a rule, it was accompanied by social tensions and growth of inequality in rural areas, which additionally complicated the already difficult circumstances of rural development. All those factors have shaped the rural space of Serbia so that today it has post-transitional characteristics.

\section{Rural space in Serbia in the post-transition period}

According to the OECD classification, rural areas have less than 150 inhabitants per square kilometre. Their economy is highly dependent on the primary sector and based on the depletion of natural resources. Very often, these areas are characterised by pronounced poverty and considerable limitations to development (BOGDANOV 2007, p. 31).

Rural areas in Serbia made in 2013 up for 47\% of Serbia's Gross Domestic Product (GDP) (REPUBLIČKI ZAVOD ZA STATISTIKU 2013). Only three counties out of 25 (excluding Kosovo and Metohija) are urban. Serbian rural areas differ also as regards distance from the market and thus conditions for product placement. This has resulted 
in differences in economic and social development, which has affected demographic trends and hence economic efficiency and quality of life.

Basic characteristics of the economic structure of rural areas in Serbia are their high share of agriculture, food industry, mining and energy production, and a low share of the tertiary sector in GDP. Main limiting factors are (BogDANOv 2007, p. 65):

- inadequate position of the agricultural sector and rural areas in development policies;

- low accumulative capacity of rural households;

- underdeveloped capital markets and unfavourable conditions in this market, uncertain investment environment;

- limited market for products and services in rural areas, problems with the purchase of products, and poor organisation of supply chains/mechanisms;

- inadequately educated workforce and low level of private entrepreneurship.

One of the biggest problems in Serbian agriculture is the large number of small and fragmented farms (see Fig. 1). Of the total number of agricultural holdings, $47 \%$ use only up to two hectares arable land. The largest number of farms (almost 80\%) has arable land of less than five hectares. Under such conditions, intensive production is hard to achieve. The average farm size is 5.4 hectares, which is significantly less compared to the average European size of holdings, which is over 20 ha (RADIVOJEVIĆ 2014 , p. 13). Small holdings process land for their own needs. Equipment, buildings and machinery are very modest in structure and of little use for earning additional income. Not all farms have tractors. The worst situation exists in Zlatibor County [Zlatiborksi okrug] in the western mountainous part of the country, where only every second farm has a tractor. More than $95 \%$ of all tractors in Serbia are more than ten years old, in some areas more than $99 \%$ (Zaječar County [Zaječarski okrug] in eastern Serbia), which again proves the lack of investment in rural areas and agriculture. However, more recently, a noticeable agglomeration of properties occurred. A small number of larger farms has gained stronger economic power, acquiring also machinery, mainly imported (RADIVOJEVIĆ 2014, p. 16).

Such characteristics of rural space in Serbia are the result of various factors, one of the most influential being the reform of the agricultural sector during the transition process. It introduced changes in ownership and privatisation of processing capacities, as well as market liberalisation and the creation of a new economic and business environment accompanied by social tensions and growth of inequality. Reform processes need, however, to be very carefully planned, managed and coordinated to avoid deterioration in quality of life, to avoid compromising the vitality of resources and serious social consequences in rural areas. Unfortunately, in the transition period, policy makers did not dedicate much attention to economic and social problems in 
rural areas. Systematic and comprehensive efforts to create efficient mechanisms of activating and exploiting the potentials of rural areas were not taken. Privatisation of cooperatives and state agricultural enterprises resulted in a large rise in unemployment. There were also no incentives for the growth of entrepreneurship and private initiative significantly reducing opportunities for alternative employment and leading to rising poverty among the rural population.

Figure 1: Registered agricultural holdings in Serbia, 2002 and 2012

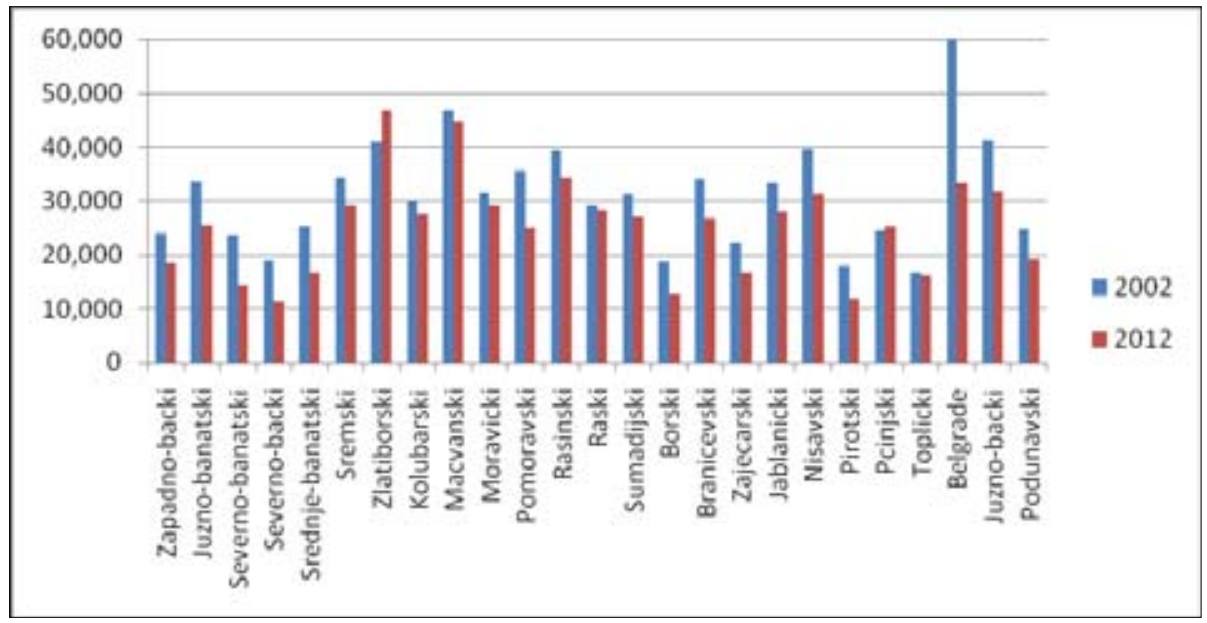

Source: REPUBLIČKI ZAVOD ZA STATISTIKU (several years)

There is a large drop in the number of registered agricultural holdings in all counties, except Zlatibor and Pčinja County [Pčinjski okrug]. In the entire country, the number of holdings decreased by almost $20 \%$. This is caused by the ageing of rural population, rural-urban migration flows, the globalisation process, etc. Despite the reduction in the number of farms, they are still significant for the local economy and the local market in food production as well as for the preservation of national resources.

The drop in the number of agricultural holdings did not mean raising their economic size. The average economic size of farms in the Republic of Serbia in 2012 was 5,939 Euros, for family farms 4,990 Euros and for legal entities and entrepreneurs 204,755 Euros. Unfortunately, the sector of family farms dominates - it accounts for $99.5 \%$ of the total number of farms in Serbia. ${ }^{1}$ The average economic size of agricultural holdings in the EU-28 (data as of 2010) was 25,128 Euros, which is more than four times above the value for the Republic of Serbia (CviJAnović et al. 2014,

These data cannot be compared with the previous period, since the Serbian Statistical Office just started to collect them. Data might be comparable with EU member countries. 
p. 23). In the EU, only Romania has a lower average economic size of farms, i.e. half of the Serbian average. There are significant regional differences in the economic value of holdings. As expected, holdings in South and East of Serbia are the poorest with an average economic value of 3,414 Euros, while the average economic value of Vojvodina holdings is 3.5 times larger, i.e. around 12,000 Euros.

Figure 2: Average economic size of farms in Serbia

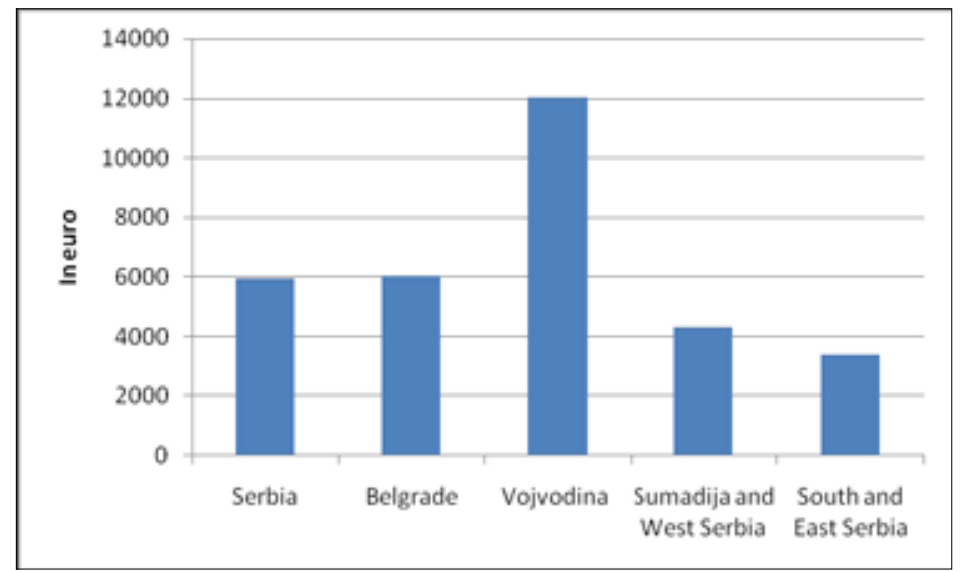

Source: PARAusić \& CVIJANOvić 2014

Small holdings in Serbia mostly earn from the sale of their agricultural products, but also from other sources: working in industry, pensions, and rarely from other activities such as tourism. (Only $0.8 \%$ of all holdings are engaged in tourism.) Almost $52 \%$ of all holdings do not have income except from agriculture (CviJANOvić et al. 2014, p. 51). The share of holdings with some income from other activities is $12.4 \%$. Most common activities are milk processing and fruit and vegetable processing. However, income from these other activities in most cases contributes very little to their budget - below $10 \%$ in more than half of the cases; only with $5.8 \%$ of holdings the share of income from other activities is more than 51\% (REPUBLIČKI ZAVOD ZA STATISTIKU 2013).

\section{The process of shaping Serbian rural space}

Economic space is shaped by a variety of factors and it is not easy to analyse, which factor has the strongest impact. This is common to all economic activities, especially with major 'space consumers' like agriculture. Considering that rural 
space in Serbia is part of the vast Southeast European agricultural space, it has been shaped also by factors that were characteristic for this region as a whole: historical background, demographic processes and different economic issues. It seems that the most significant historical moment for rural development in Southeast Europe was the establishment of Communism. Communist rule in this area lasted for decades during the $20^{\text {th }}$ century and left a significant mark on agriculture as well as on economy at large. Impact of Communism, however, varied significantly within Southeast Europe (JORDAN 2009, pp. 91-92). The main difference was between the system in Yugoslavia and the rest of Southeast Europe. The Yugoslav self-management system admitted private ownership of arable land resulting in a share of around 70\% (TASCHLER 1989). Countries like Romania, Albania and Bulgaria had all undergone forced collectivisation, with some differences between the first two and Bulgaria. In Bulgaria, collectivisation was supported by huge state investment, while in Albania and Romania farmers were forced to join agricultural cooperatives, which later had been transformed into state farms (JORDAN 2009, pp. 93-94). Serbian farms worked mostly for subsistence, apart from self-managing enterprises mainly in the Vojvodina. Investment was only possible from additional income, e.g. from employment in local industry, combined with daily commuting to work and work on farm after having ended daily work in industry. In Serbia, privatisation started at the beginning of the 1990s, but was interrupted by events like Yugoslavia's disintegration, UN embargo, political instability, NATO bombing. After the political change in 2000 , privatisation was continued, but determined by the request for restitution. The large agricultural enterprises in Vojvodina were partly privatised and partly just transformed with the state remaining the largest owner. Privatisation of agriculture in Serbia had, however, not such a big effect because of its predominant private structure during the Communist period.

Changes by transformation affected also very much the demographic structure of rural areas. Migration from rural to urban areas was predominant resulting sometimes in depopulation. This process sees Serbia in the forefront of European countries (MANIĆ et al. 2012). Rural population decreased by $10.9 \%$ in the period $2002-2011$, and the following examples show the extent of the problem:

- 1,000 rural settlements have less than 100 inhabitants - every fifth settlement is on the verge of disappearing;

- In eastern and southern Serbia population decrease amounts to $19 \%$;

- In Šumadija and western Serbia rural population dominates (52.6\%).

Depopulation is extremely high in some areas, even exceeding 30\% (Pčinja County). The hardest situation exists in the eastern and southern parts of Serbia, where the population decreased by $19 \%$ during the last census period. Exceptions are two urban counties (Belgrade [Beograd] and the Southern Bačka County [Južnobački okrug]) as well as one rural county (Raška County [Raški okrug]). The first two 
counties are the destinations of migrant flows from rural areas. (Belgrade and Novi Sad are the two largest urban centres in Serbia and the seats of these counties.) At the same time, they have a significantly higher natural increase rate than most of the other counties. The Raška County is located in the southwestern part of Serbia, where the Muslim ethnic group is concentrated, which has a higher natural increase rate than other communities in Serbia.

Figure 3: Rural population in Serbia 1991-2011

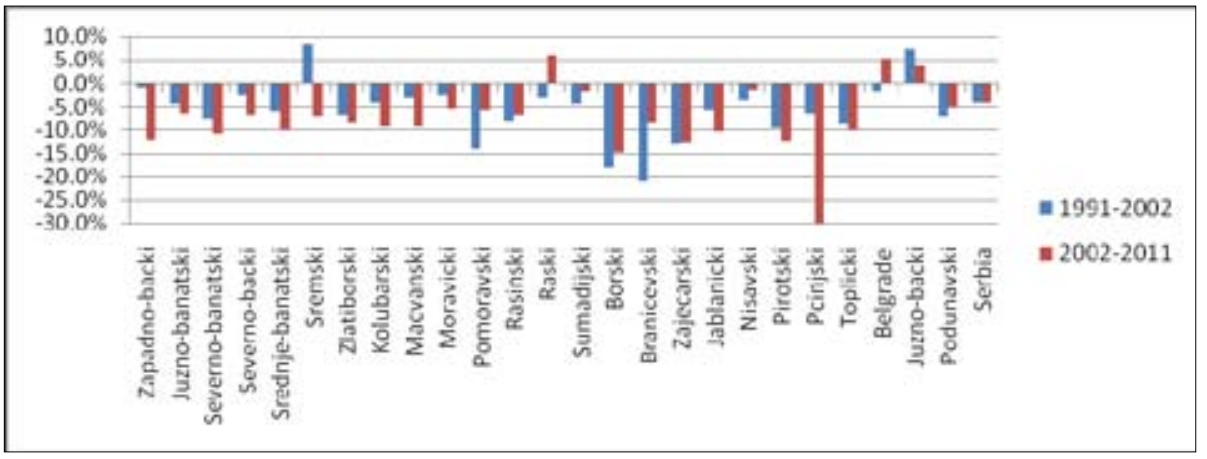

Source: RePUBLIČKI ZAVOD ZA STATISTIKU (several years)

Such unfavourable demographic development resulted in a very unfortunate age structure. According to the latest census, around $66 \%$ of the entire rural population in Serbia is over 65 years old and only $13.9 \%$ belong to the category up to 14 years of age (REPUBLIČKi ZAVOD ZA STATISTIKU 2015) (see Fig. 4).

This situation could result in a lack of labour force in the future. Also from the economic point of view, such an age structure consequently leads to a problematic educational structure, and all that creates a vicious circle of underdevelopment.

If we deepen this demographic analysis towards agricultural households, we see some amazing facts: every third farmer has 65 years and more, and less than $5 \%$ are up to 35 years of age. The higher the age of farmers, the more investment and openness towards innovations decrease. Older people do not accept new trends, or even when they are familiar with new developments that can lead to higher productivity, they do not perceive themselves as potential investors. The problem is the relatively high investment compared to a short amortisation period, which makes investments hard to pay off (PANTIĆ \& MiLJKović-ŽIVANović 2010, p. 3). Also educational structure is an important fact related to potentials for economic and social development in rural areas (see Fig. 5). 
Figure 4: Age structure of the rural population in Serbia

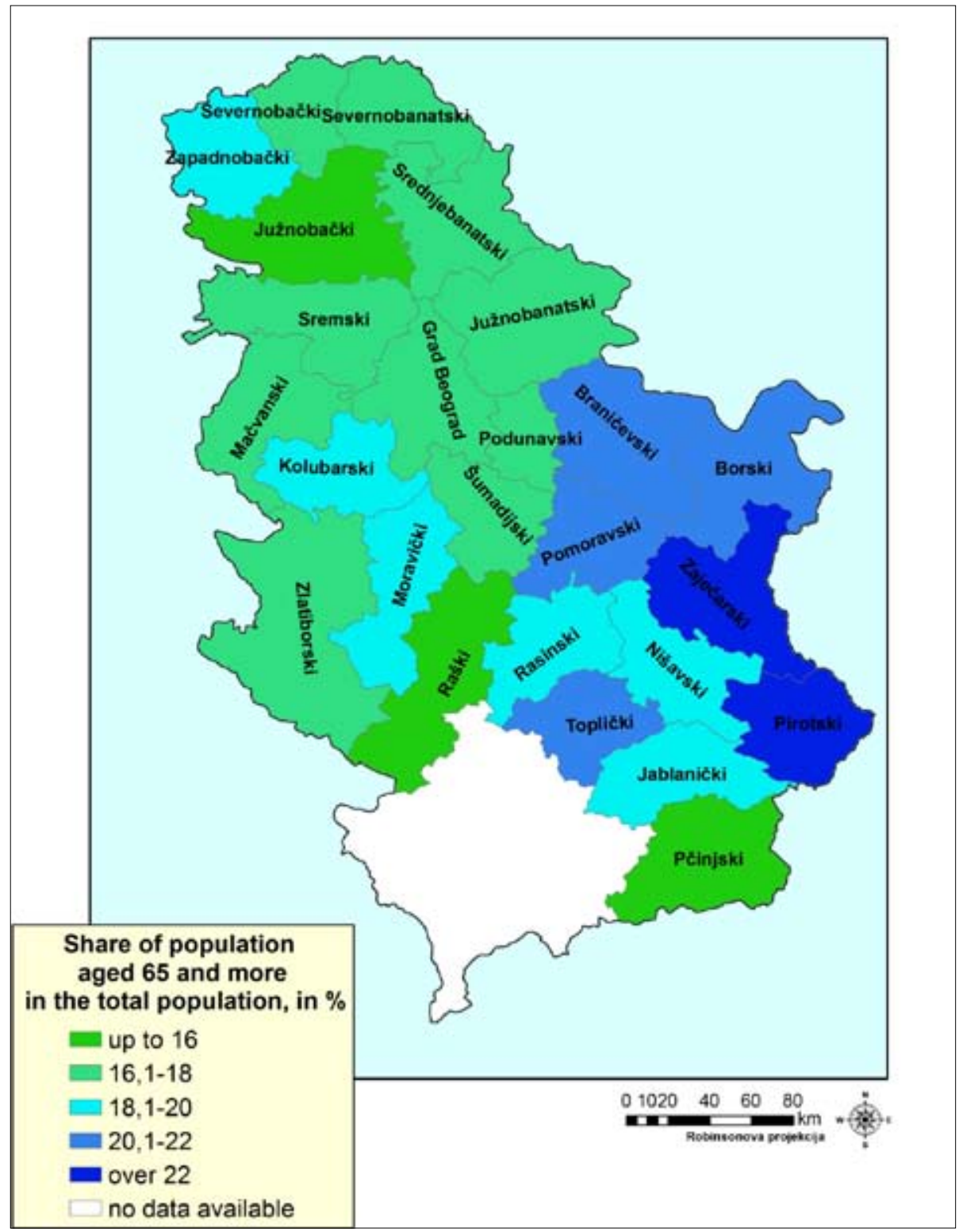

Source: REPUBLIČKI ZAVOD ZA STATISTIKU 2015; authors' analysis 
Figure 5: Educational structure of the rural population in Serbia, 2013

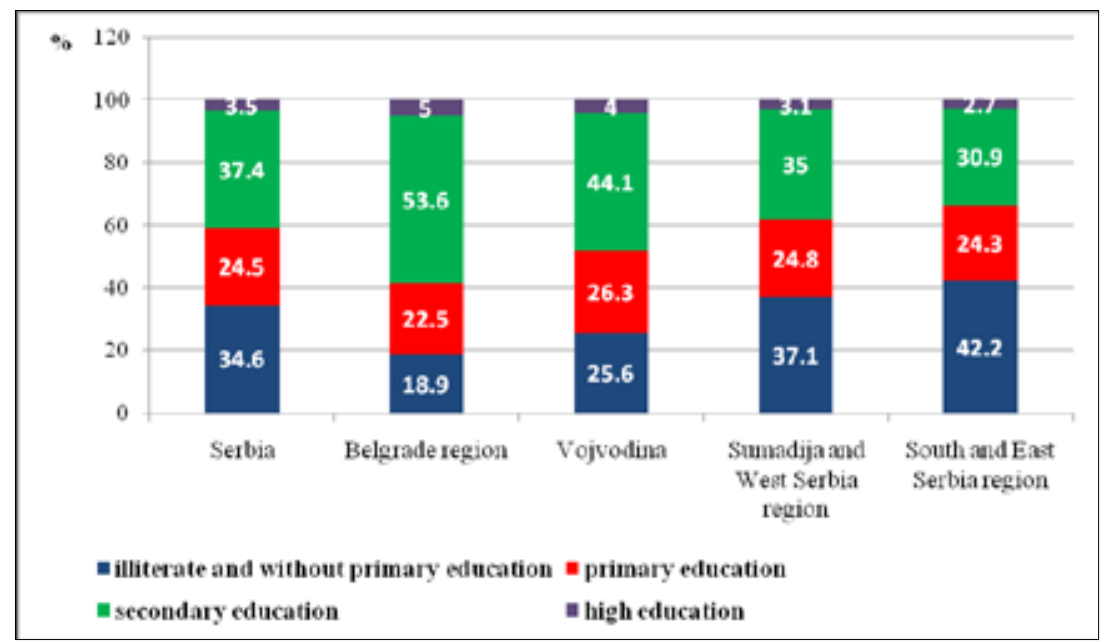

Source: RePUBLIČKI ZAVOD ZA STATISTIKU 2015; authors' analysis

A considerable number of people older than 15 years of age in Serbian rural areas falls into the category of illiterates or people without finished primary school (almost $35 \%$ ). More than half of the Serbian rural population has never entered the secondary school system. Regions with an unfavourable educational structure coincide with those of the most problematic age structure. In southern and eastern Serbia, more than $60 \%$ of the rural population older than 15 years of age has never entered the secondary school system. The percentage of people with tertiary education is quite small (around $3.5 \%$ in entire Serbia, up to $2.7 \%$ in southern and eastern Serbia).

Moreover, the education of farmers is also weak, while a formal education is missing. Only $1.4 \%$ of them finished a faculty of agriculture or a higher agricultural school, $3.3 \%$ have completed a secondary agricultural school or an agriculture course, while $60 \%$ of them have only practical agricultural experience without any course or other agriculture-related training (REPUBLIČKI ZAVOD ZA STATISTIKU 2013). Only in the category of the largest agricultural holdings (over $50 \mathrm{ha}$ ), age and educational characteristics of managers are favourable. These farms have higher entrepreneurial and commercial potential. Unfortunately, many holdings will not be able to transform into commercial farms, given the modest potential, the vitality of existing manpower and resources at their disposal.

Rural space in Serbia with such historical background and demographic processes did not have much opportunity for faster and better economic development. This can also be seen by labour market analysis. In the observed transitional period, there is a slight decrease in both rates of unemployment for Serbia, i.e. the ratio 
between unemployed and employed as well as the ratio between unemployed and all inhabitants. This trend is determined by decrease of the unemployment rate in two urban (Belgrade and Southern Bačka) and five rural counties (four in Vojvodina and one in Šmadija and western Serbia). Despite this trend, unemployment rates are at a very high level. Of particular concern is the ratio between unemployed and employed. In some counties, the number of unemployed is significantly higher than the number of employed. The problem is even larger if we take pensioners into account. One employed in Serbia financially supports 0.56 unemployed and 1.22 pensioners. The best ratio is in Belgrade, where one employee supports 0.83 pensioners and 0.23 unemployed, and the worst in Zaječar County with 2.02 pensioners and 0.88 unemployed on one employee. The only other county with the ratio of pensioners vs. employed lower than one is Southern Banat County [Južno-banatski okrug], an urban area (see Fig. 6).

\section{Figure 6: Unemployment rates in Serbia}

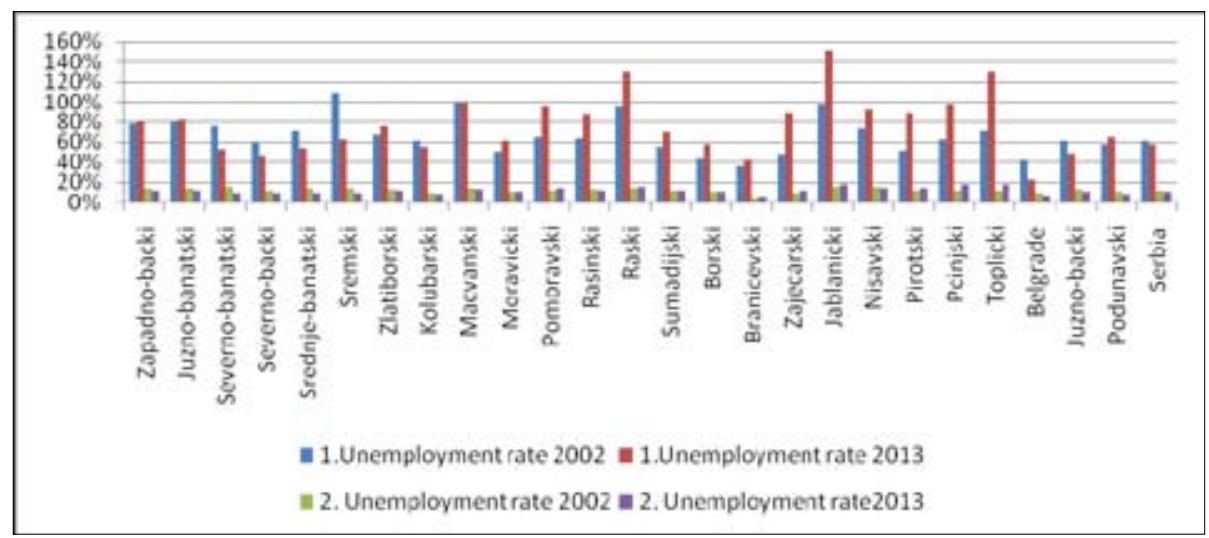

Sources: RePUBLIČKI ZAVOD ZA STATISTIKU (several years); REPUBLIČKI ZAVOD ZA STATISTIKU 2015; authors' analysis

Unemployment rate 1 is calculated as the ratio between the number of unemployed and the number of employed. Unemployment rate 2 is calculated as the ratio between the number of unemployed and the total number of inhabitants.

In the next decade, the ratio between employed and pensioners will deteriorate even further. It is estimated that the population in working age will decrease by a cumulative $8 \%$, as the baby boom generation, i.e. those born after World War II, retires (ARANDARENKo 2011, p. 21).

Labour Force Survey data for 2013 show that in rural areas one third of the employed (35.5\%) works in agriculture, forestry and fishery, $14.3 \%$ are craftsmen and 
$13 \%$ are service and sales workers (REPUBLIČKI ZAVOD ZA STATISTIKU 2014). There is a tendency of diminishing the number of employees in the surveyed industries (see Fig. 7). This could be due to the technological progress and development, which makes it possible to produce the same product with a smaller number of employees. Unfortunately, the share of Gross Value Added (GVA) in agriculture in total GVA shows the opposite. The share of GVA in agriculture in total GVA in 2002 was $15 \%$ and in 2013, it was $9.4 \%$ (REPUBLIČKI ZAVOD ZA STATISTIKU, several years). Productivity in the wheat sector increased (average yield in $\mathrm{kg}$ ) by almost $40 \%$ in the company and cooperative sector and by $20 \%$ with family farms. Productivity in corn production, however, fell by $30 \%$ and almost $60 \%$, respectively.

Figure 7: Employees in agriculture, forestry and fishery in Serbia, 1991-2011

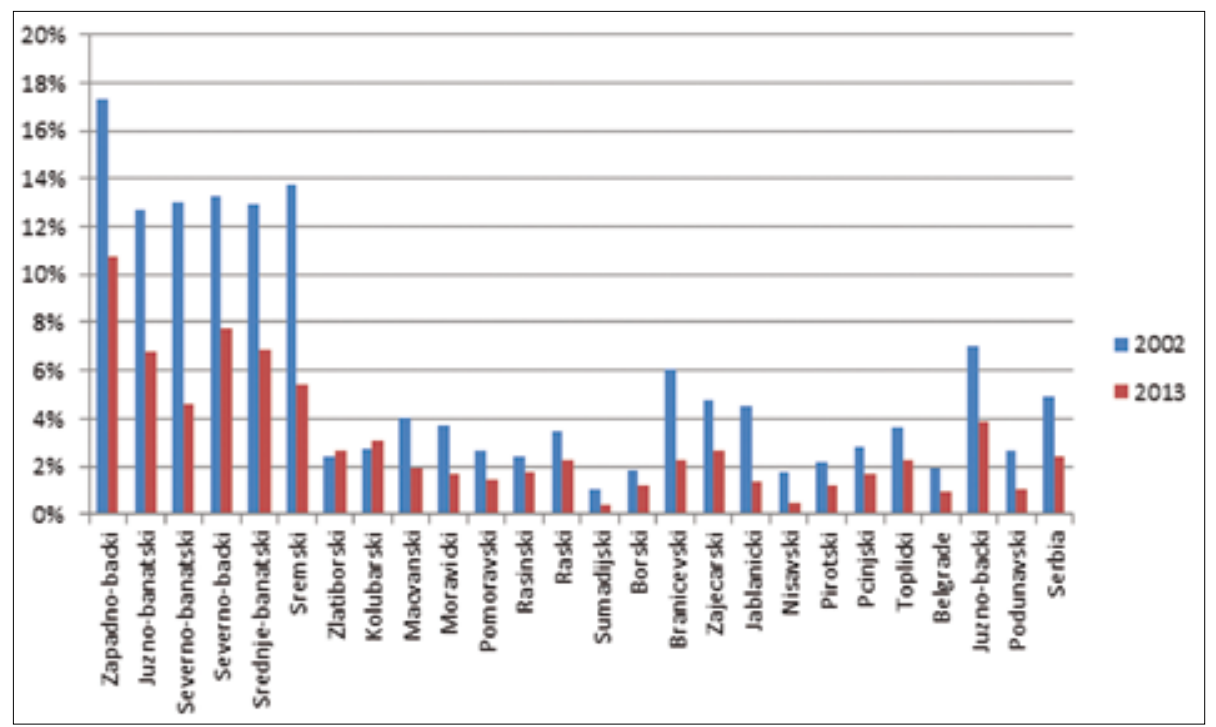

Sources: REPUBLIČKI ZAVOD ZA STATISTIKU (several years), REPUBLIČKI ZAVOD ZA STATISTIKU 2015

However, a part of the rural population, although officially registered as unemployed, works on their own farms. They are engaged in agricultural production and sell their products, so that they are not 'really' unemployed. Informal employment in rural areas is $33.1 \%$ (in urban areas $14.7 \%$ ), and it is predominant in agriculture with $62.1 \%$ of the total employment in agriculture (Bogdanov \& BABović 2014, p. 4). The majority of persons in this way engaged in agricultural activities on farms are members of the narrower or wider family $(56.3 \%)$, the share of farm holders is $43.6 \%$, while the share of permanently employed on farms is $0.1 \%$ (REPUBLIČKI ZAVOD ZA STATISTIKU 2013). 
Taking into account the above-mentioned conditions, the small size of investment flows towards rural areas is not surprising. To support development, investments in rural infrastructure would be most desirable, but according to statistical data they are quite modest, and so is investment in market support, farming or non-farming activities, etc. (see Fig. 8).

Figure 8: Distribution of investments in Serbia by counties, 2002 and 2013

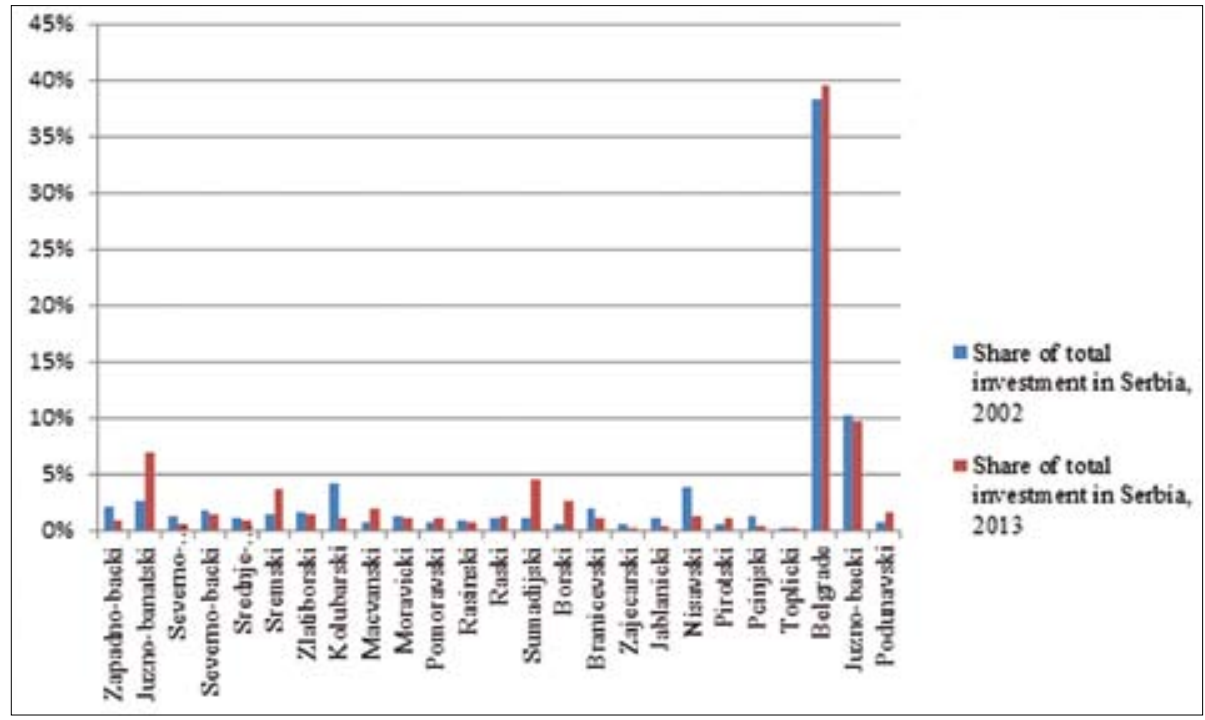

Source: REPUBLIČKI ZAVOD ZA STATISTIKU 2015

There is an obvious spatial disparity of investments, which increased in the transition period (see Fig. 9). The largest share went to Belgrade, i.e. almost $40 \%$ of all investment. A significantly smaller and decreasing share (around 10\%) went to the other urban district, i.e. South Banat County [Južnobanatski okrug]. With the exception of one rural county, in all rural counties the share of investments is significantly lower than $5 \%$. The worst situation occurs in Toplica County [Toplicki okrug], with a share of $0.2 \%$ in the total investments in Serbia in 2002 and 2013.

With the exception of two rural counties, Zaječar and Toplica, all other counties are characterised by a decrease of relative investment in agriculture in the transition period. The largest decrease is documented for Srem County [Sremski okrug], i.e. by about $43 \%$. The transition period obviously brought significant disinvestment in agriculture due to low support from the agricultural budget, limited credit support and no efficient financial markets that would help raise funds for modernisation, merging and consolidation of agricultural funds. All this resulted in strong differences in GDP 
per capita among regions. While in Belgrade it is slightly higher than $170 \%$ of the country's average, and in Vojvodina 102\%, in Šmadija and western Serbia it amounts to $67.5 \%$ and in southern and eastern Serbia to $63.2 \%$ (REPUBLIČKI ZAVOD ZA STATISTIKU, several years).

Figure 9: Share of investments in agriculture, forestry and fishery in total investments in Serbia, 1991-2011

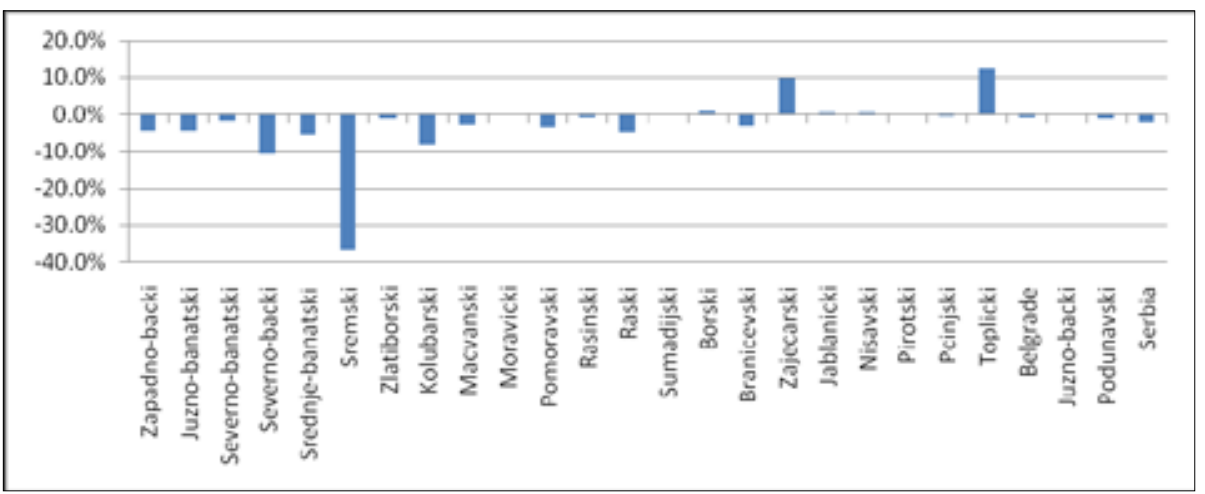

Source: REPUBLIČKI ZAVOD ZA STATISTIKU 2015

\section{Serbian agricultural production in the post-transition period}

High fragmentation of properties, lack of investment and high-quality machinery, and disorganisation can be regarded the main problems of Serbian agriculture. Its significant lagging behind Europe results from all these factors. The development of small agricultural holdings is limited by the lack of financial sources. Their equity is low, bank credits are hardly available, and they cannot earn much from sale of their products because of the low prices of their goods and low productivity, as well as the lack of markets. There are problems with the purchase of agricultural products and due to the import of large quantities of cheaper products from neighbouring countries. Production of small holdings is mostly extensive and traditional. Lack of investment, inefficient organisation of production and transport of goods resulted in low productivity and a production characterised by frequent oscillations and high dependence on climate conditions (PARAuŠIĆ \& CVIJANOvić 2014). Because of the small size of used land, those farms cannot apply the economy of scale, which leads to higher unit cost prices and low marketability. With modest and uncertain market surpluses, they lack quantity, quality, continuity and flexibility to satisfy the needs of consumers. 
That is why they are mostly subsistence or semi-subsistence farms with a low level of specialisation in production.

In Serbia, the average area of total ( $0.54 \mathrm{ha})$ and used ( $0.48 \mathrm{ha})$ agricultural land per capita is enough for a sustainable food supply of the population. Unfortunately, these indicators are not the result of better management in agriculture, but of the reduction in the total number of residents. Agricultural land shows a decreasing tendency throughout the country due to its continuous shift to non-agricultural uses (residential, industrial and infrastructure facilities) or its conversion to forest land in mountainous, demographically significantly deserted areas. There is also a trend towards an increase of unused (abandoned) agricultural land. In some rural municipalities, worryingly large areas of agricultural land have been abandoned, which means a loss in potential agricultural production (Š́EVARLIĆ 2015). This trend is due to various reasons regarding demographic characteristics of farmers (depopulation, unfavourable age structure), but also inadequate agricultural and rural policy with high costs for intermediate goods and insufficient market prices, lacking opportunities to sell products, bad transportation and warehouse facilities, etc. Especially problematic is the issue of use or lease of stateowned agricultural land. Use of agricultural land changed over the observed period, but changes are unevenly distributed by regions: in Vojvodina it increased by $120 \%$, whereas in other regions the trend was negative (see Fig. 10).

Figure 10: Used agricultural land in Serbia, 2002 and 2012, in ha

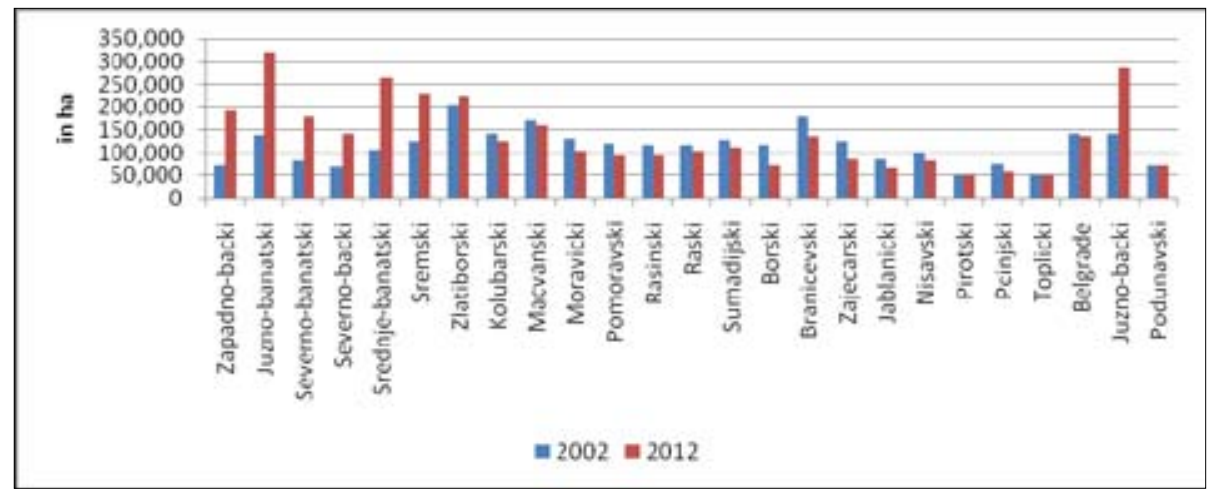

Source: REPUBLIČKI ZAVOD ZA STATISTIKU 2015

Vojvodina has the highest level of agricultural land use, which is very important on the background that it has the best quality of arable land in Serbia. Serbia proper shows a significant decrease in arable land by almost $15 \%$. Also the area under vineyards has decreased significantly, i.e. by $53.7 \%$ on the average for Serbia in the last 50 years. This results from the contraction of vineyards with extensive production due to reduced available workforce, and the inability of small agricultural holdings to 
raise investments in modern economic productive vineyards (ŠEVARLIĆ 2015). Areas under orchards have increased (almost by $8 \%$ ) in Serbia as a whole and especially in Vojvodina as the result of long-term investment and production specialisation of economically stronger farms towards fruit production, which is more profitable and export-oriented.

The most important products of intensive agriculture in Serbia are wheat and corn, industrial crops, followed by fruits and grapes, while the production of vegetables is evenly distributed over the country, with small farms prevailing and producing mostly for their own needs or the local market. Wheat and corn production is highly concentrated on Vojvodina $(60 \%$ of total wheat production and $70 \%$ of total corn production) and northern parts of Serbia proper, mostly around the larger rivers (Sava, Danube, Morava) (see Fig. 11).

Figure 11: Production of wheat (a) and corn (b) in Serbia by kind of producers, 2002 and 2013

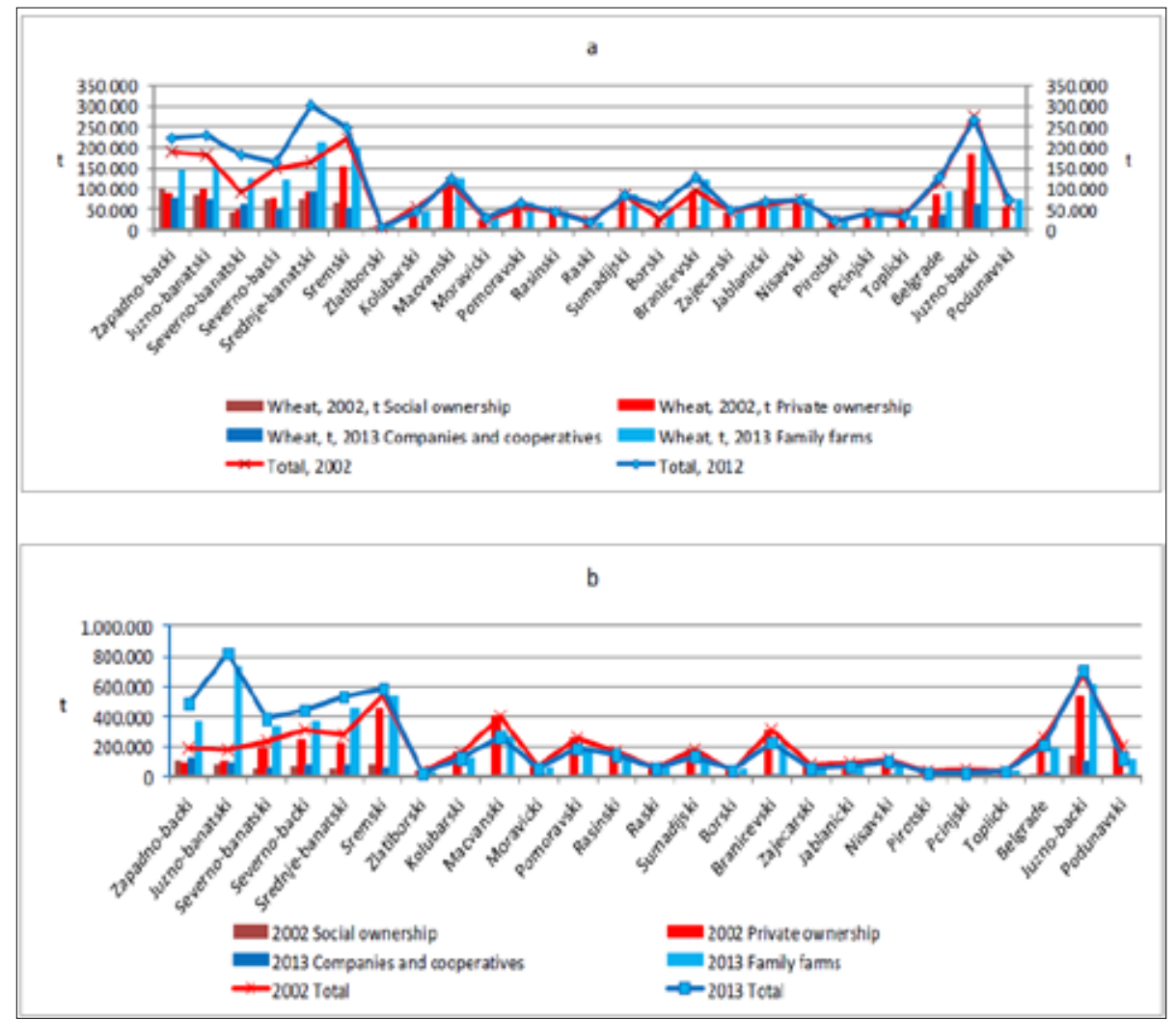

Source: REPUBLIČKI ZAVOD ZA STATISTIKU 2015 
In 2002, a large part of wheat production in Vojvodina came from public companies and cooperatives. During the transition period these enterprises were privatised or went bankrupt. Family farm production of wheat dominated in other parts of Serbia. In 2013 the share of wheat produced in companies and cooperatives in Vojvodina decreased by about $15 \%$, and family farm production increased by almost $60 \%$. This means that the total amount of wheat production in Vojvodina during the observed period increased by $27 \%$. Having in mind that family farms are mostly small and poorly equipped, this is a negative trend. Small family farms mostly produce for their own needs and not for the market. Corn production in Vojvodina rose by almost $30 \%$ in 2013 compared to 2002 . The majority of corn is produced in small family farms. However, the total quantity of corn produced did not change over time, which marks a drop in the production offside Vojvodina. Family farms mostly use corn to feed animals. Since their number decreased over time, they need less corn.

Land useful for wheat and corn production is also suitable for industrial crop production. Typical cultures are sugar beet and sunflower, and their highest concentration is on Vojvodina, which also had the highest growth of production during the period 2002-2013, i.e. by almost 50\% (with the exception of Srem County).

Serbia has favourable climate and soil conditions for growing fruit trees. However, according to census data, orchards occupy only $4.8 \%$ of the total agricultural land (2012). A large portion of fruit plantations in Serbia is extensive, with low levels of agrotechnology or even without any measures in plantation. Despite that, Serbia is a leading producer of fruit in the region (see Fig. 12). For some fruit species, it is a leading country in Europe and worldwide (e.g. raspberry). Thanks to its duty-free status with the Russian Federation and the CEFTA agreement, a large portion of table

Figure 12: Fruit and grape production in Serbia, 2002 and 2013

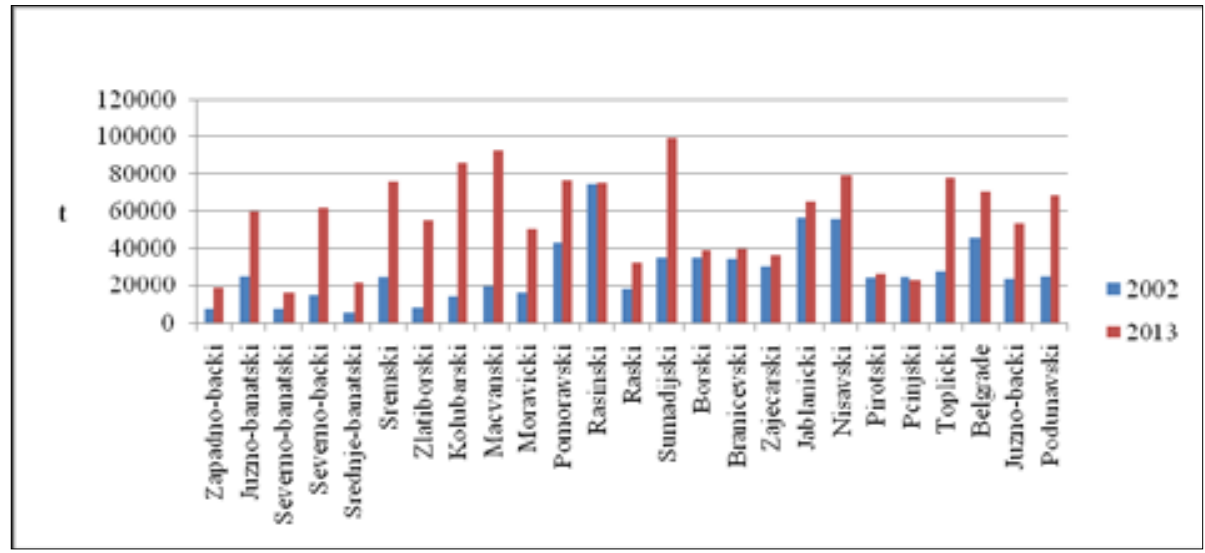

Source: REPUBLIČKI ZAVOD ZA STATISTIKU 2015 
fruit is placed on these markets, while frozen and processed fruits are mainly exported to the EU. In the structure of exports of agricultural products fruit and fruit products participate with 17\% (KeSEROVIĆ \& MAGAZIN 2014).

The production of fruits significantly increased in the transition period, especially in Šumadija and western Serbia, where it more than doubled. That region dominates with $40 \%$ of the total production. It is followed by southern and eastern Serbia with a share of more than $30 \%$. Grape production has also been recovering during the last decade. Most suitable are the eastern and southern hilly parts of the country as well as the slopes of Fruška gora and Vršac Mountains [Vršačke planine] in Vojvodina. There are nine wine areas in Serbia, where a lot of small family farms started production (IvANisEvić et al. 2015).

\section{Conclusion}

Serbia has only three urban counties, out of 25 , which means that it is among the most rural countries in Europe. The economy of rural areas is highly dependent on agriculture, food industry, mining and energy production. Unfortunately, in the transition period, rural areas and agriculture had an inadequate position in development policies resulting in an unfavourable economic, social and demographic structure.

The poor economic structure is shown by several indicators. In agricultural production, small and fragmented farms prevail. Their production is mostly extensive, for their own needs, market access is occasional and highly dependent on weather conditions. Their buildings, machinery and other equipment are outdated, investments are scarce and the ability to obtain additional funds is insufficient. Their products are not competitive on the market due to unfavourable agricultural policy (high prices of fertilizers and other inputs, low subsidies, cheap imports), inefficient production, poor use of modern agricultural techniques, etc.

Just a small number of holdings can live on their own business. The main reason is that the government has not created an ambience for more intensive entrepreneurship development in rural areas and did not evaluate of potentials and comparative advantages. The process of privatisation of cooperatives and state agricultural enterprises, as a part of transition, resulted in a huge rise of unemployment. With low opportunities for alternative employment, this led to rising poverty with the rural population. Unfavourable employment opportunities and low living standard enhanced the trend towards migration to larger cities. Investment in rural infrastructure is at a low level. All this results in an increasingly bad demographic structure of the rural population, with less and less young and educated people that could drive the development. 
The situation in Serbia's rural areas has been formed, similar to the other countries of Southeast Europe, under the influence of the Communist doctrine, but with some peculiarities. The Yugoslav self-management system allowed the persistence of a significant share of private farms, different from Romania, Albania and Bulgaria. These small private farms relied on subsistence production and very small investments, only if additional income was available. When transition and privatisation started, this did therefore not have such a big impact on Serbia. The lower share of state-owned large enterprises meant a low share of large private companies in the agricultural sector. Nevertheless, noticeable agglomeration of properties occurred in recent times. There is a small number of larger farms with some economic power allowing them significant investments and having younger and educated workforce. The majority of them is located in Vojvodina.

Vojvodina has the best quality of land and there is an increase of used agricultural land, in contrast to the rest of Serbia. The most important agricultural products in Serbia are wheat and corn (highly concentrated on Vojvodina), industrial crops (also in Vojvodina) and then fruits (in all of Serbia, but mostly in Šumadija and western Serbia) as well as grapes, while the production of vegetables is evenly distributed over the country, mostly for own use and the local market.

The development of rural areas in Serbia requires better targeting of development policies that suit their specific needs, increased investment in infrastructure, support of development of agricultural production and other profitable activities, as well as entrepreneurship development.

\section{References}

Arandarenko M. (2011), Supporting strategies to recover from the crisis in South Eastern Europe: country assessment: Serbia. Budapest, ILO.

Bogdanov N. (2007), Mala ruralna domaćinstva u Srbiji i ruralna nepoljoprivredna ekonomija, Beograd, UNDP. <www.undp.org.yu>

Bogdanov N., BABović M. (2014), Radna snaga i diverzifikacija prihoda na poljoprivrednim gazdinstvima u Srbiji - stanje i izazovi za politiku ruralnog razvoja. In: Zbornik radova. Završna konferencija, Primena podataka Popisa poljoprivrede 2012. u analizi stanja poljoprivrede i u planiranju agrarne politike u Republici Srbiji, Republički zavod za statistiku, Republika Srbija, Subotica 28-30 maja 2014, pp. 262-288. Beograd.

Cvijanović D., Subić J., Paraušić V. (2014), Poljoprivredna gazdinstva prema ekonomskoj veličini i tipu proizvodnje u Republici Srbiji, Popis poljoprivrede - Poljoprivreda u Republici Srbiji 2012. Beograd, Republički zavod za statistiku.

Ivanisević D., JAKsiĆ D., KoraC N. (2015), Vinogradarski atlas. Beograd, Republički zavod za statistiku. 
JoRDAn P. (2009), Development of Rural Space in Post-Communist Southeast Europe after 1989: A Comparative Analysis. In: Revija za geografijo - Journal for Geography, 4-1, pp. 89102.

Keserović Z., Magazin N., Voćarstvo Srbije - stanje i perspektive. <http://media.popispoljo privrede.stat.rs/2014/Dokumenta/Radovi/03\%20Vocarstvo\%20Srbije\%20\%E2\% $80 \% 93 \% 20$ stanje $\% 20 \mathrm{i} \% 20$ perspektive.pdf $>$

Manić E., Popović S., Molnar D. (2012), Regional Disparities and Regional Development: The Case of Serbia. In: Mittelungen der Österreichischen Geographischen Gesellschaft, 154, pp. 191-210.

Pantić M., MilJković-Žıvanović J., (2010), Regional Differences between Rural Areas of Serbia in Population Ageing and Agricultural Activities: Case Studies of the Inđija and Knjaževac Municipalities. In: Spatium International Review, 22, pp. 29-37.

Parausić V., Cvijanović D. (2014), Economic size of holdings in Serbia and measures for their strengthening. In: Zbornik radova. Završna konferencija, Primena podataka Popisa poljoprivrede 2012. u analizi stanja poljoprivrede i u planiranju agrarne politike u Republici Srbiji, Republički zavod za statistiku, Republika Srbija, Subotica 28-30 maja 2014, pp. 43-61. Beograd.

RadivoJević D. (2014), Poljoprivredna mehanizacija, oprema i objekti, Popis poljoprivrede Poljoprivreda u Republici Srbiji 2012. Beograd, Republički zavod za statistiku.

RepubličKi ZAVOD ZA STATISTIKU (ed.) (2013), Census of Agriculture - Agriculture in the Republic of Serbia 2012. Beograd.

RePUBLIČKi ZAVOD ZA STATISTIKU (ed.) (2014), Anketa o radnoj snazi (= Bilten, 578). Beograd.

RepubličKi Zavod za statistiku (ed.) (2015), Opštine i regioni u Republici Srbiji. Beograd.

RePUBličKi ZAVOD ZA STATISTIKU (ed.) (several years), Censuses 1991, 2002, 2011. Beograd.

ŠEvarlć M. (2015), Poljoprivredno zemljište, Popis poljoprivrede 2012 - Poljoprivreda u Republici Srbiji. Beograd, Republički zavod za statistiku.

Taschler B. (1989), Agricultural structure. In: Breu J. (ed.), Atlas of the Danubian Countries, p. 322. Wien, Deuticke. 
